\title{
Tourism and Cultural Identity: The Case of the Polynesian Cultural Center
}

\author{
By Jeffery M. Caneen*
}

\begin{abstract}
Since Boorstein (1964) the relationship between tourism and culture has been discussed primarily in terms of authenticity. This paper reviews the debate and contrasts it with the anthropological focus on cultural invention and identity. A model is presented to illustrate the relationship between the image of authenticity perceived by tourists and the cultural identity felt by indigenous hosts. A case study of the Polynesian Cultural Center in Laie, Hawaii, USA exemplifies the model's application. This paper concludes that authenticity is too vague and contentious a concept to usefully guide indigenous people, tourism planners and practitioners in their efforts to protect culture while seeking to gain the economic benefits of tourism. It recommends, rather that preservation and enhancement of identity should be their focus. Keywords: culture, authenticity, identity, Pacific, tourism
\end{abstract}

\section{Introduction}

The aim of this paper is to propose a new conceptual framework for both understanding and managing the impact of tourism on indigenous host culture. In seminal works on tourism and culture the relationship between the two has been discussed primarily in terms of authenticity. But as Prideaux, et. al. have noted: "authenticity is an elusive concept that lacks a set of central identifying criteria, lacks a standard definition, varies in meaning from place to place, and has varying levels of acceptance by groups within society" $(2008, p$. 6). While debating the metaphysics of authenticity may have merit, it does little to guide indigenous people, tourism planners and practitioners in their efforts to protect culture while seeking to gain the economic benefits of tourism.

This paper uses the case of the Polynesian Cultural Center to argue that cultural identity rather than authenticity is the salient variable to set in relation to tourism, and that it is a concept easier to both understand and apply. Recent anthropological research has concluded that culture is as much invented contemporaneously as transmitted. Culture, the way people live, changes with or without tourism. Identity related to culture, is the thing of value that guides and gives meaning to life. Rather than victimizing indigenous people, tourism empowers them to create cultural identities that suit and serve themselves.

${ }^{*}$ Chair, Brigham Young University, USA. 


\section{Authenticity and Tourism}

The historian Daniel Boorstein initiated the debate on tourism and cultural authenticity in a chapter of his still-influential critique of modern life The Image (1964). In it, he argued that the successes of modern society had produced "extravagant expectations" in us. As we harbor, nourish and enlarge these expectations, we begin to demand the impossible. In terms of tourism, we demand "our two-week vacation to be romantic, exotic, cheap, and effortless" ( p. 4). In an effort to satisfy our extravagant expectations and impossible demands, the tourism industry creates for us an illusion of authenticity. For Boorstein, authenticity is available, but cannot be had as cheaply as we demand. Therefore we get pseudo authenticity to pacify us.

Boorstein viewed mass tourism as the regrettable end result of a transformation of travel that had previously been limited to the serious and meaningful pursuits of a high-minded elite who were willing to endure the necessary costs and discomforts that a real adventure required. Instead, tourists are sold their own preconceived images of reality in place of the reality itself in what he described and decried as a "pseudo- event"; an inauthentic representation of host culture in which "people everywhere obligingly become dishonest mimics of themselves" (p. 103). He saw tourism as but one facet of modern culture in which consumers purchase a contrived image of something real in preference to the real thing itself. Since the publication of Boorstein's book - now 43 years - the tourism literature has discussed the relationship between tourism and culture in terms of authenticity.

In a reply to Boorstein's critique, MacCannell (1976) suggested that at its essence tourism is a quest for authenticity. He placed tourism in the context of what he saw as an all-encompassing revolution of modernity. "For moderns" he said, "reality and authenticity are thought to be elsewhere..." (p. 3). He suggested that as pilgrims in days past traveled in search of the sacred, modern tourists travel in search of authenticity in the "other" that they lack in their own lives. Ironically, for MacCannell, tourism produces "staged" or inauthentic authenticity. He took a kinder view of tourists and tourism, rejecting Boorstein's condescending assertion that they eschew authenticity in favor of more self-ratifying and comfortable representations.

MacCannell suggested that primitive or non-modern people live their lives totally exposed to their associates "and do not suffer from anxiety about the authenticity of their lives" (ibid., p. 93). But modernity imposes a separation of life into what he called "front" and "back" regions. The front is the public part of life that we show to others. The back is the private part of life that we show only to our intimate associates and is inaccessible to outsiders. Most host/guest interaction occurs in the front region. But for MacCannell, the back is where authenticity lies, and to be admitted is the objective of the tourist no less than of the anthropologist.

MacCannell proposed that hosts open the back part of their lives to guests along a continuum of "stages". In stage one, what the guest sees is entirely front. In stage six, what the guest sees is entirely back. The intermediate stages 
are various combinations of front and back. MacCannell assumed that tourists gullibly accept any stage as authentic as long as it agrees with their preconceptions. In this view tourists are easily fooled. They believe that authenticity lies only in the "other" and that the "other" must be therefore authentic.

In response to MacCannell, Cohen (1979) rejected the idea that tourists are gulled into accepting staged authenticity as though it were the real thing. $\mathrm{He}$ suggested that authenticity has two components: the nature of the scene or event and its impression on the tourist. Cohen described four possible situations related to authenticity. In the first situation, which he called "authentic", the scene or event is both objectively real and accepted as such by the tourist. In the second situation, for which he borrowed MacCannell's term "staged authenticity" the scene is inauthentic, but is accepted by the tourist as authentic. The third situation "denial of authenticity" is the reverse of staged authenticity. The event is authentic but is cynically perceived as staged or inauthentic by the tourist. Finally, Cohen suggested a situation he termed "contrived" in which the event is both staged and accepted as such by the tourist. Ultimately, Cohen credited tourists with more sophistication and discernment than either Boorstein or MacCannell. He recognized that tourists find satisfaction from both the authentic and the inauthentic and that attractions like Las Vegas and Disney World are recognized and enjoyed as sites of authentic inauthenticity. In Cohen's view, authenticity is not an "all or nothing" proposition. It is formulaic.

Greenwood's somewhat hysterical Culture by the Pound (1977) is another oft-cited contribution to the debate. He was one of the first to describe and label the process of cultural "commoditization". He did this in the context of the Alarde, a Basque festival in Spain. Greenwood observed the festival both before and after it was promoted to tourists. The tourist gaze created a "mask of cynicism", and a "loss of meaning" for the townspeople in regards to their festival. Greenwood worried that "culture is being packaged, priced, and sold... if you have money in hand, it is your right to see whatever you wish" (p. 136), and that "commoditization of culture ... robs people of the very meanings by which they organize their lives" (p. 137). In this view, money corrupts culture. The very fact that money is involved strips away authenticity and meaning.

Cohen made another important contribution in response to the idea of commoditization (1988). He noted that the concept of "authenticity" at the center of the debate was often illustrated but never defined. He suggested that the implication in Boorstein's, MacCannell's, and Greenwood's writings was that the authenticity they envisioned was similar to the authenticity sought by a museum curator. He noted that authenticity, for curators and ethnographers, is principally a quality of pre-modern life, and of cultural products produced prior to the penetration of modern Western influences. They "seek to recapture the society and culture of the people whom they study as these had been before the 'contaminating' contact with the Western world" (p. 375). Cohen suggested 
that authenticity is not so strictly defined or apprehended by tourists or locals. It is not represented by a slavish fixation on some arbitrary point in time.

He noted for example that for some, the presence of plastic drinking cups in a traditional Thai village was an offense to their sense of cultural authenticity. He suggested that most tourists would look past this to gain an overall sense of authenticity. In citing Greenwood's assertion that a cultural product loses its meaning when it is performed for money, Cohen argued that it would be absurd to suggest that all popular music is devoid of meaning for the artists because it is commercialized (p. 382). He made a point that is particularly relevant to this paper when he proposed that culture is negotiable rather than received, and that a cultural element that may be seen as inauthentic today may come to be seen as authentic over time - even by experts (p. 379).

Hughes (1995) brought a post-modern, existential outlook to the definition of cultural authenticity. He made it clear that the very concept of authenticity in a tourism context is both problematic and essentially political. Hughes placed the problem of tourism and cultural authenticity within a larger, philosophical debate surrounding a "crisis of representation" (p. 782). To Hughes, the difference between "staged" and "authentic" is meaningless because the terms refer to a reality which is itself constructed.

Hughes' line of reasoning was new, but he ultimately came to the same conclusion as Boorstein three decades earlier. Tourists consume images. Cultural representations are about aesthetics rather than authenticity. $\mathrm{He}$ attributed this to the dual differentiating/homogenizing influences of globalization (p. 783). As a result, the notion of culture as "a territorially insulated place-centered" phenomenon that nourishes and guides individuals cannot be supported in this new age. Culture cannot be thought of as authentic or inauthentic because culture as we refer to it does not exist. There cannot be an authentic symbol of a non-existent object. To Hughes, cultural authenticity can now only be represented through individuals' assertions of cultural identity (p. 799).

Wang (1999) expanded on Hughes' philosophical analysis of the meaning of authenticity. He suggested that tourists seek their own authentic selves rather than authentic, external objects. He plausibly maintained that tourists perceive an attraction to be authentic to the degree that it supports their preconceived ideal of authenticity. Recent additions to the literature are still preoccupied with authenticity - mostly with its definition (Wang, 2007), (Reisinger and Steiner, 2006), (Belhassen and Caton, 2006).

\section{Authenticity and Anthropology}

While authenticity in the tourism literature has evolved along an ever more metaphysical and unapplied path, a parallel and more-pragmatic discussion has been underway in the literature of Cultural Anthropology and Ethnic Studies. There, the issue of cultural authenticity has been buried altogether. Beginning on several fronts simultaneously in the early 1980's, authors like Hobshawn 
and Ranger (1983), Handler (1983) and Linnekin (1983) built upon earlier musings by Eisenstadt (1972) and Braun (1965) in their collective contention that the traditions of culture are invented rather than transmitted.

Hobshawm and Ranger (1983) made a distinction between custom and tradition. Custom or simply "the way people live" is ever-changing; in premodern societies as well as in the modern. "Custom cannot afford to be invariant" they maintained, "... because life is not so" (p. 2). As life changes, custom must change to accommodate it. Some degree of flexibility is a requirement of survival. Tradition, on the other hand is seen as fixed, or at least of ancient origin. But Hobshawm and Ranger used the most revered and seemingly timeless traditions of Scottish Highlanders, Welsh quaintness, even the pomp of the British monarchy to show that what appears to be of ancient origin is actually a comparatively recent invention; created for political purposes. They saw nothing nefarious in this. Societies, they claimed, need stability as well as flexibility. "The object and characteristic of 'traditions', including invented ones, is invariance" (p. 2). Authenticity is irrelevant because the cultural tradition is in fact an invention.

Handler (1984) studied the cultural traditions of French-Canadians in the context of the Quebecois nationalist movement. While noting that much of the cultural tradition held dear by the Quebecois was of recent invention, he maintained that it was cultural identity rather than content that provided guidance and continuity to the group. He took issue with objectivism as applied to culture. Culture is not an object that exists in place or time that can be referred to. It is a symbol that is constantly invented. Handler concluded that the "sense of identity is not continuous with the past ... but a new construction - referring to the past, to be sure, but symbolically created in the present" (p. 57).

In a similar investigation of traditional Hawaiians, Linnekin (1983) argued that tradition is a conscious undertaking - a model of an idealized past that people use in the construction of their identities. "The inheritance of an authentic tradition ... [is] illusory" (p. 241). She noted that the elements of traditional Hawaiian culture in 1983 did not correspond to the experience of any particular past generation of Hawaiians. Linnekin concluded that while traditional authenticity is a concern of academics, it is irrelevant to the meaning of tradition and identity in the present. Like Handler, she asserted that cultural identity rather than authenticity is the glue that holds a group together. She illustrated that "isolated facts have been transformed into symbols of Hawaiianness and accorded a significance without precedent in aboriginal Hawaiian society" (p. 245).

Hanson (1989) came to similar conclusions regarding the traditions of New Zealand Maoris. He showed how two of the founding traditions of Maori culture were most likely an invention of European whites who sought to assimilate the natives into the white culture by inventing creation myths similar to those of the West. But whereas the whites were attempting to demonstrate the worthiness of Maoris to be assimilated, today's Maori activists embrace and use the invented traditions to "bolster a sense of their own ethnic 
distinctiveness and value" (p. 893). Hanson takes pains to point out that the fact that culture is an invention should not engender suspicion or fear among anthropologists that what they produce is not knowledge. "Inventions are precisely the stuff that cultural reality is made of" and are worthy of study (p. 897). Like Handler and Linnekin, Hanson saw cultural identity rather than authenticity as the proper object of study, respect, and preservation.

In terms of cultural authenticity of the museum variety, anthropologists were catching up to the earlier conclusions of historiography. "The past can only be told as it truly is not was" (Wallerstein, 1974 p. 9). The past itself cannot be observed and studied. It can only be interpreted. Interpretations of indigenous, pre-literate cultures are if anything particularly subject to invention. If authenticity describes a faithful representation of the past, and the past cannot be known, how can a comparison be made? Authentic cultural traditions cannot be preserved or recovered because they cannot be known. This fact manifestly does not make modern-day traditional culture valueless or irrelevant for indigenous people.

Indigenous people are appropriately selective in constructing their identities. They logically do not embrace all aspects of their traditional past that can be supported with evidence. Wrigley, for example, discouraged what he saw as a prevailing and misguided nostalgia for "traditional" cultures (1992). He gave evidence that traditional, pre-modern societies were uniformly poor and that human suffering was endemic. Life for the non-elite majority was most likely short and unpleasant. Likewise the Japanese Anthropologist Yamashita (2003) has shown that while traditional Bali is considered a living "paradise," its documented, "authentic" past included slavery, widow burning, and almost-constant warfare. Yet, he contends, "paradise-Bali" of leisure, the arts, idyllic villages, and richly-symbolic festivals is the authentic identity of Bali and the Balinese today. Authenticity for its own sake requires indigenous people to embrace elements of their traditional pasts that are unlikely, in their own estimation, to bring them satisfaction and happiness. Identity, on the other hand, allows indigenous people to pick and choose representations of tradition that suit them.

If cultural authenticity of the museum variety does not exist in any meaningful way, what can it possibly mean to say that tourism has either a positive or negative impact upon it? We contend that what tourists see and describe for themselves as cultural authenticity, is seen and felt by the host population as cultural identity or ethnicity. The meaningful question, contrary to the decades-old debate becomes: what is the effect of tourism on identity? This is not a trivial question as cultural or group identity; ethnicity if you will, is a major contributor to social cohesion, order, and human happiness. Tourism that enhances identity is a social good. Tourism that degrades identity is a problem indeed. 


\section{Identity}

Identity is a term used throughout the social sciences to describe an individual's comprehension of himself. It is strongly related to self image, rolebehavior, and life-expectations. Identity has both psychological and sociological meanings. It is how human beings perceive and make sense of themselves and others. Identity guides and gives meaning to life. Since the 1980s there has been a burgeoning interest in identity-related issues in the social sciences because psychologists and sociologists believe that cultural changes attendant with modernity and globalization have made forming and sustaining a sense of identity problematic (Cote and Levine, 2002).

Globalization, like culture and authenticity, is a contested term loaded with inferred meaning. In its most simple form it refers to the increasing interconnectedness of people and communities throughout the world. Some equate it with the spread of Western culture or the Americanization of world culture. In any event, one well-documented result of globalization is the homogenization of culture; a "universalizing" tendency in which people become more and more alike (Robertson, 1997). It is in this context that psychologists posit an increasing crisis of identity as people yearn to differentiate themselves from an increasingly homogenous mass. According to the American Psychiatric Association, identity disorders leave people being unsure of what they believe in, uncommitted to any future course of action, open to manipulation, and unaware that they should pass a sense of meaning to their children (American Psychiatric Association, 2000).

Identity in traditional cultures relied on authority and obligation. Modern identity, and it needs to be repeated here that all the world today is subject to modernity, is a matter of choice (Cote and Levine, 2002, p. 1). Identity in the modern context is seen as "multiple categorizations of the individual by both self and others that vary by situation, influence behavior, and constitute life's meanings" (Weigert, et. al., 1986, p. 27). Culture is one of the multiple characterizations that vary through choice in response to life's circumstances. Swidler produced the seminal work in cultural identity (1986). She argued that cultures do not dictate social identity so much as they provide a "tool kit" of resources from which people can choose as they construct the identity that best meets their strategic aims (p. 273). It follows that those with a strong cultural identity have tools at their disposal to use in avoiding the unhappy symptoms of identity disorder that those without cultural identity lack.

In terms of traditional, indigenous people, cultural identities are both created and chosen to embody positive points of difference with the prevailing, hegemonic culture of the West. Sissons (2005) concluded that traditional, indigenous cultures are every bit as modern as settler cultures, but that they are "characterized by an affirmation and conscious re-appropriation of tradition in opposition to the modernity proclaimed by post-settler states" (p. 12). He railed against the "oppressive authenticity" required of indigenous people and insisted that it is up to indigenous people to define their own identities in the present (p. 18). Likewise Duval (2004), in noting tourism's role in the 
negotiation of ethnicity, concluded that "with the spread and ubiquity of Western Culture and modernity, 'culture' has come to mean points of difference with the dominant Western 'other"' (p. 59).

Robertson popularized the term "glocalization" to describe this paradoxical aspect of globalization: the widespread desire to become more different as we become more alike. What he termed the "simultaneity --- the co-presence --- of both universalizing and particularizing tendencies" (1997). He related this to increasing claims to indigeneity by peoples throughout the world. It is strong evidence that individuals and groups feel a need for culture to represent an important aspect of their identities.

Even in the midst of modern, Western society there is a movement among non-ethnic, fully-assimilated whites to re-establish a cultural identity. In Ethnic Options, Waters (1990) described the widespread practice among white urbanites of choosing some element of their actual or fictional genealogy to emphasize and declare as the living cultural portion of their personal identities. Gans (1979) described the emergence of "symbolic ethnicity" by means of which fully-assimilated whites develop a nostalgic allegiance to the culture of an older generation. He noted a "sincere desire to return to these imagined pasts, which are conveniently cleansed of the complexities that accompanied them in the real past" (p. 11). Akiba (2007) gave evidence that the success of American immigrant school children was positively related to the strength of ethnic identity maintained by their families. In other words, children from families who embraced their cultural identity were more successful than children from families that stepped away from their ethnicity. Thibault (2006) showed that a sense of cultural identity gave people an enhanced ability to decode the expressions of emotion in others of the same culture. Tsuda (2000) discussed the many advantages flowing from the maintenance of Japanese cultural identity in Brazil. The conclusion: a strongly-felt, positively-portrayed cultural identity enhances personal and societal well-being.

\section{Tourism and Identity}

What then is the impact of tourism on the cultural identity of indigenous people? Oakes (1997) described the impact of tourism in Guizhou China. He described how the presence of tourists made local residents aware of the value of their traditions and created in them a pride and "sense of identity" that they had not previously enjoyed. While he indicated that it was the tourists who decided what looked "authentic" - confirming Hughes' contention that authenticity is merely an aesthetic - in the end, tourism provided the indigenous minority with a "forum for making claims about themselves and their villages" (p. 67). Tourism provided them with the means to invent their cultural traditions and imbue them with a meaning that enhanced their sense of identity. 
Wood (1993) noted that tourism is often appropriated by locals in their symbolic constructions of culture, tradition and identity. Fjellman (1993), while conceding tourism's role in the commoditization of culture, noted that these "inauthentic" visions allow the host population to celebrate with visitors what its history and traditions really "ought to have been". It is the anthropologist Yamashita who most cogently described the symbiotic relationship between culture and tourism (2003). Noting the hostility of anthropology towards tourism, he recommended a rejection of what he termed the "narrative of loss". He demonstrated, using Bali as example, that culture is an invention that uses attractive elements of the past to construct a useful tradition for the present. Yamashita recognized tourism as a major tool in this effort. He recommended a new "narrative of emergence" in which "tourism does not simply consist of staging the local culture for the tourists: it is also the arena in which negotiations concerning cultural identity take place" (p. 150). He stated that rather than being powerless victims, whose culture is destroyed by hegemonic outsiders, indigenous people consciously use tourism to define themselves in a positive light and thereby accumulate political power. Culture is inevitably invented; tourism is simply one means of so doing.

Prideaux, et. al. worked around the metaphysical difficulties inherent in authenticity when they proposed that what tourism commoditizes ultimately morphs into a "new authenticity" $(2008$, p. 3$)$. This idea recognizes the reality of cultural invention and the role that tourism plays in the process. They used the example of the Australian Aboriginal boomerang to illustrate; explaining that while boomerangs produced by Aboriginals today are dissimilar to "traditional" boomerangs in both design and function, they are nevertheless "authentic" in the sense that they are accepted as symbols of identity by modern Aboriginals.

Jamal and Hill made an attempt to develop a framework for authenticity that could be used by tourism practitioners. They conceptualized a typology of authenticity based on ontological differences in the understanding of space and time. They concluded that there exists objective authenticity in relation to historic time, constructive authenticity in relation to heritage time, and personal authenticity in relation to resident/visitor time (Jamal and Hill, 2008, p. 22). After valiantly striving to give authenticity some structure, they too conclude that "understanding and managing the 'authenticity' of tourist objects, sites, events and experiences involves dealing with the politics of authenticity, i.e., issues of identity" (ibid., p. 33).

Identity provides people and communities with power: economic, political, and social. Picard observed that "in multi-ethnic Indonesia, Bali is looked upon with 'unconcealed envy' for their success in asserting their own ethnic identity and cultural worth. This internal admiration flows from the external (touristic) admiration" (1997). Indigenous groups should be aware of the fact that culture inevitably changes. Touristic interpretation of cultural identity can be chosen by its owners or imposed by outsiders. 


\section{Case Study: The Polynesian Cultural Center}

The aim of this study is to propose a conceptual framework that explains the relationship between tourism and identity. Such theory building is an inductive exercise, requiring primarily qualitative data to posit a generalization based on a small number of observations (Tashakkori and Teddlie, 2003 p. 15). To that end, a holistic, single-case analysis of the Polynesian Cultural Center was conducted over an extended period of time (1999 - the present). In his comparison of the relative merits of various research designs, Yin (1994, p. 9) concluded that case study methods have a "distinct advantage" when seeking answers to explanatory questions about contemporary events over which the investigator has little or no control. The preceding literature review has shown that identity formation is a contemporary process that is not subject to experimental control. The unit of analysis for this study is the Polynesian Cultural Center, a non-profit commercial organization whose purpose is to present Polynesian culture to tourists visiting Hawaii.

In keeping with the methodological requirements detailed in Yin (ibid., $p$ 20 ), this study was designed to collect triangulating data from multiple sources that represent the viewpoints of the participants. Five types of data were collected for this study over a period of eight years:

1. A review of the literature to determine the history, characteristics, impacts, structure, and operation of the PCC.

2. Individual interviews of 137 student workers who represent the indigenous cultures of their home islands.

3. Individual interviews with key executives of the PCC and other important stakeholders.

4. Seven hundred seventy (770) internal PCC employee exit surveys.

5. Direct observation.

The data was analyzed using the iterative explanation-building techniques described by Yin (ibid., p. 111).

In the sphere of Anthropology, ethnography, a particular type of case study (Thomas, 2003), is the preferred and most-widely used research method. It is the "art and science of describing a group or culture" (Fetterman, 1998, p. 1). Yamashita's previously described investigation of tourism in Bali (2003), Greenwood's critique of tourism in Spain (1977), Duval's analysis of the effects of tourism on the culture of the Caribbean (2004), and Oakes' review of ethnic tourism in China (1997) can all be classified as ethnographies or singlecase, holistic case studies.

There is ample precedent for using case-study analysis to create or refine a conceptual framework or theory. Eisenhardt (1989) listed a number of widelycited case studies in business management that resulted in theoretical models. Lowi (1964) reviewed a number of contributions made to political theory by way of case studies in business and public policy. Connell and Lowe (1997) used a multi-case study to develop a theory of international hotel branding. 
Riley (1995) used case study methods to develop a theory of prestige conference in travel. Hottola (2004) used the cases of India and Sri Lanka to create a dynamic model of culture confusion in relation to tourism. Therefore, in line with accepted case study methodology (Tellis, 1997), persons were identified, appointments were arranged, interviews using an interview guide were conducted, archival materials were obtained, and the case study was developed and written.

\section{The PCC}

The Polynesian Cultural Center (PCC) is a commercially successful cultural heritage tourism attraction located 35 miles from Honolulu in Laie, Hawaii, USA. It is owned by the Church of Jesus Christ of Latter-Day Saints and operated as a non-profit entity in conjunction with the adjacent Hawaii campus of Brigham Young University (BYUH). The center covers 42 acres and consists of a live-performance theater, 30,000 square feet of retail shopping space, an IMAX ${ }^{\mathrm{TM}}$ cinema theater, three restaurants, and seven island villages surrounding a man-made tropical lagoon. The villages present ongoing interpretations of the traditional cultures of Hawaii, Tahiti, Fiji, Tonga, Samoa, The Marquesas and Aotearoa (New Zealand.)

\section{History}

The center was originally created through an indigenous, grassroots effort to provide a means for Polynesian students to fund their education, and the staff is composed primarily of part-time student workers and performers from the various Polynesian islands. The product is highly labor intensive with approximately 1,000 total employees serving 2,500 visitors per day on average. Roughly 35,000 students have financed their college education through employment and with the sponsorship of the Polynesian Cultural Center.

In 1865 The Church of Jesus Christ of Latter-Day Saints (LDS) purchased a 6,000-acre plantation in Laie as a "gathering place" for Hawaiian converts. The construction of the LDS Temple in Laie in 1919 attracted even more church members from throughout the South Pacific. Although a small village, Laie became, in its way, a rather cosmopolitan place with islanders of several different cultures living together (O'Brien, 1983). Shortly after the end of World War II, church members started a fishing festival as a means to raise money to build a new chapel in the place of one that had previously been destroyed by fire. The festival, called the Hukilau, included a luau and Polynesian entertainment and its advent coincided with a post-war surge in Hawaiian tourism. The Hukilau was staged weekly for several years and succeeded in attracting tourists beyond the intentions of its creators (Swapp, 1999). 
In 1955 the Church College of Hawaii (now Brigham Young University Hawaii) was established in Laie to educate the children of a rapidly growing church membership throughout the Pacific. Most of the students did not have sufficient means to fund their education, and Laie was so remote that part-time employment opportunities were very rare. In the course of time some of the students revived the idea of the Hukilau, and with the help of college faculty put together "Polynesian Panorama" -- a production of authentic Pacific island songs and dances -- which was produced weekly in Waikiki in the late 1950s and early 1960s (Swapp, 1999).

The success of Polynesian Panorama combined with the difficulty of moving the cast to Honolulu each week eventually generated the idea of constructing a Polynesian village to entertain tourists in Laie. With the funding and assistance of the church, the Polynesian Cultural Center was created and opened to the public in 1963. Its purpose was, and remains, to provide a means for students to earn a living and fund their education at BYU-Hawaii.

\section{Today}

The Polynesian Cultural Center is the most visited and most successful commercial tourism attraction in Hawaii which is, in turn, the most visited tourism destination in the Pacific region. The climax of the night show each evening is the performance of the Samoan fire knife dance. In it, a wellmuscled young man runs onto the darkened stage with what appears to be a longish, flaming baton but is actually a razor-sharp Samoan fire knife. He is naked but for a tapa-print lavalava and bracelets of kukui nuts around his wrists and ankles. He is by turns menacing and friendly as he passes the flames over his body demonstrating that he is impervious to pain. Soon drums begin and the dancer twirls and tosses the fire knife in a ten-minute display that is simultaneously war-like and gymnastic. It is a crowd pleaser.

The fire knife dance appears to be, and is taken to be, an authentic cultural artifact of traditional Samoan life - a practice with ages-old significance and meaning, emblematic of Samoan identity. It is in fact an invention of the Polynesian Cultural Center and Hollywood. It evolved into its present form through the combined creativity of Mike Grilikis, a PCC consultant and the husband of movie star Lorraine Day (Ferre, 1988), and Freddie Letuli an expatriate cultural entertainer and Hollywood movie actor who was influenced by the fire-eating displays of a Hindu fakir (Letuli, 2004).

The Samoan fire knife dance could be seen to represent the worst of modern mass tourism with hosts of outsiders traveling in guided groups and finding pleasure in "inauthentic and contrived attractions" - gullibly enjoying "pseudo-events" (Boorstein, 1964). All the while the traditions of a pure, primitive culture are bastardized and degraded - drained of their deeper spiritual meaning and offered as a commodity to unknowing outsiders (Krippendorf, 1987). Modern Samoans, however, both indigenous and expatriate, treasure the fire knife dance as an authentic cultural icon of real, Samoan identity. Fire knife dancers today are heroes in Samoa and among Samoans throughout the world (Letuli, 2004 pp. 84-85). The fire knife dance, 
created for and through tourism, though inauthentic in the museum sense, is an authentic element of Samoan cultural identity today.

When confronted with its technical inauthenticity, Samoan workers at the PCC vehemently maintain that the fire knife dance is "authentic" because 1.) it was created by Samoans, 2.) the knife that is set aflame and used in the dance evolved from a traditional Samoan battle weapon, and 3.) because it is Samoans that continue to change and refine both the knife and the dance. Authenticity, then for these indigenous people consists not in the faithful representation of historic practices, but in the ethnic identity of those who create, own, and control it. It is authentically Samoan because authentic Samoans say it is. Or in other words, identity rather than authenticity is the primary consideration for these indigenous people.

How does employment at the Polynesian Cultural Center affect the felt identity of it student employees? Former student employees describe their PCC experience as a personal validation of individual identity and worth. Typical are the reflections of Meli, a graduating senior from Fiji who worked as a cultural performer in the Fijian village for four years and also danced in the canoe pageant. He grew up in suburban Suva, Fiji and noted that prior to his employment at the PCC he felt that "culture was for old women. Me and my friends were embarrassed by Fijians clinging to old ways. We all wanted to get to America or Australia or New Zealand - modern countries with the good life. But now after seeing how much my Fijian culture is appreciated by Americans and by Japanese, and after learning so much more about it myself, it makes me proud to be Fijian. I've taken a second look at my culture. [The manager of the Fijian village] has taught me a lot and has tried to shame me into acting more Fijian - showing more respect, sharing. When I came, my mother told me to marry an American and find a good job in America. But I want to go back to Fiji. I am Fijian. That's where I should be".

Lomo, a Samoan who was formerly a student worker and who is now the vice president of operations for the PCC said that "the PCC is an important cultural resource throughout the Pacific. About $30 \%$ of all tourists that visit Oahu will visit the PCC. But $100 \%$ of all Polynesian tourists who visit Oahu will come to the PCC. They want to see how they are represented. And they are very vocal when they see something they don't like. They say 'this is not the way it was done' and we look into it to try to make sure that everything is very authentic. But that's not so easy. There are a lot of different ideas about what is authentic. There's no absolute authority you can turn to. A lot of these people have an agenda. So we have to choose a version. But we are very serious about it. I am Polynesian too. We want to do it right".

In verification of the dual homogenizing/differentiating effects of globalization, a pan-Polynesian identity is evident at the PCC and many of the student-workers refer fondly to the bonds of brotherhood that they forged with fellow employees from other island nations. Bil, a native Hawaiian noted: "We all dance for every culture [in the night show]. Some cultural purists don't like this, but it would be impossibly expensive to only have Hawaiians do Hawaii, and only Tongans do Tonga, and only Tahitians do Tahiti. Besides, we are all 
Polynesians. We're all brothers. We all came from the same place. We learn to appreciate each other more that way. Let's face it - there aren't that many of us in the world. We should stick together".

Student-workers who are graduating and therefore leaving their jobs at the PCC are given an internal "exit survey" to complete. The great majority of the data gathered by the survey relates to common employment satisfaction issues. But there is a single question on the survey that asks the students to characterize the degree to which their appreciation of their own native culture has changed over the course of their PCC employment. An analysis of exit surveys over a period of eight years indicates that virtually $100 \%$ of studentworkers say that appreciation for and identification with their culture has increased or greatly increased during their employment. The only significant variation among groups in response to this question relates to student-workers from Hawaii and New Zealand. Employees from those areas are significantly more likely to say that their appreciation has increased rather than greatly increased.

Why might Hawaiians and Maoris be less-effected than Samoans, Tongans, Tahitians, Fijians, Cook Islanders, and Marquesans? Naomi, a Maori girl from Rotorua, New Zealand offered one explanation: "In Tonga, everyone in Tongan. We [Maoris] are a minority in our own country. We can't take our culture for granted. We all know the difference between Pakeha [white] and Maori culture. We need to appreciate it and protect it or it will disappear. I learned more about my culture at the PCC, but I had a real appreciation for it before I came here". Hawaiians and Maoris are both indigenous minority groups within a larger settler culture and are likely, therefore to be more aware of what makes their cultures unique and desirable. It should also be noted, however, that Hawaii and New Zealand have stronger tourism industries than do the other Polynesian countries represented at the PCC. Naomi's mother and grandmother are both cultural performers in the tourism industry in Rotorua.

Student-workers from Hawaii and New Zealand are also of mixed biological ethnicity to a much greater extent than employees from the other Polynesian islands. Bil from Hawaii, for example, while claiming Hawaiian as his ethnicity, is less than $25 \%$ biologically Hawaiian. Naomi's father is white and she is therefore at least as Pakeha as Maori, although she identifies herself as Maori. In terms of identity, biological authenticity is as problematic as cultural authenticity, and as Elkin (1967), Linnekin and Poyer (1990), and Sissons (2005) have all noted, half-caste or mixed-blood aboriginals are the most likely to make a militant claim to indigenous identity.

\section{Conclusions}

The Polynesian Cultural Center is the prototype of the commercial cultural attraction. It offers a staged interpretation of traditional Polynesian culture as a commodity to visitors who understand completely the produced nature of their experience. They recognize the result, not as authentic but as a representation 
of the authentic. McKercher and du Cros (2002) were convincing in their argument that tourists prefer to keep some distance from cultural authenticity in any event. What tourists see at the PCC is almost as rare in real-life, modern-day Polynesia as the representations in Williamsburg are in real-life, modern-day Virginia. This may be a cause for anguish among anthropologists and travelers of Boorstein's description who yearn to experience the quaintness of an untouched, primitive way of life. But that does not exist. The PCC offers an experience that tourists value. Almost one million of them visit the attraction each year. Almost thirty percent are repeat visitors.

In the process of serving up Polynesian culture of the past to this horde at a profit, the PCC is itself a vehicle for the inevitable invention of Polynesian culture of the present. The fire knife dance is typical. It is not authentic in the museum sense of the word. A visitor to pre-contact Samoa would not have been treated to a fire knife display. But the fire knife dance is very much a part of authentic Samoan cultural identity today. It was created by Samoans for tourists. As Crapanzano discovered in a different cultural context it is much easier to believe something of yourself once you have convinced others of it (1980). So it is with tourism and culture.

What tourists see as a representation of authentic culture, the Polynesian student-employees of the PCC see and feel as their own authentic cultural identity; based on the past to be sure, but created in the present - largely through the agency of tourism. It is one part of their personal identities. Indigenous Polynesians are not, for the most part, subsistence village dwellers living in grass huts. The student-workers at the PCC while strengthening their Polynesian identity are simultaneously being trained as accountants, computer programmers, and even anthropologists. Their cultural identity provides boundaries and guidance and meaning to their lives. It preserves ways of being and thinking that are alternatives to those of the global culture in which they all live.

In MacCannell's later work Empty Meeting Grounds (1992) he argued that in tourism, culture becomes the servant of commercialism and loses its deeper meaning in the lives of locals. He would have included the student-employees at the PCC as among those who are victimized and "exploited" by tourism (p. 8). In the same volume, however, he described tourism as "an ideological framing of history, nature and tradition; a framing that has power to reshape culture" (p. 1). In context, MacCannell surely assumed that tourism's power to reshape culture was wielded by some sinister, outside, corporate power. Our extended observations of the Polynesian Cultural Center and discussions with its employees lead us to the conclusion that tourism empowers rather than victimizes indigenous people. Horne (1986) likewise discovered that it is locals who use tourism "as the principle vehicle for pre-selected legends, icons, rituals and festivals to project an 'approved public culture"' (1986, p. 11). Ryan (1999) described how indigenous Maoris in New Zealand took control of tourism and used it to create their own identity rather than have an identity imposed upon them. Tourism, as Yamashita (2003) also concluded, cannot be seen as some external, polluting influence on culture. Cultures change 
constantly and "tourism is one of the main sites in which cultural innovation takes place" (p. xiv).

\section{A Model of Cultural Identity}

Figure 1 illustrates both the internal and external influences of and on cultural identity. It depicts the synergistic nature of the relationship between the image of authenticity perceived by tourists and the felt cultural identity of local or indigenous people. This model purports tourism's central role in the negotiation of identity while recognizing that other of the homogenizing / differentiating influences of glocalization affect both host and guest perceptions of the indigenous culture.

\section{Figure 1. The Authenticity/Identity Connection}

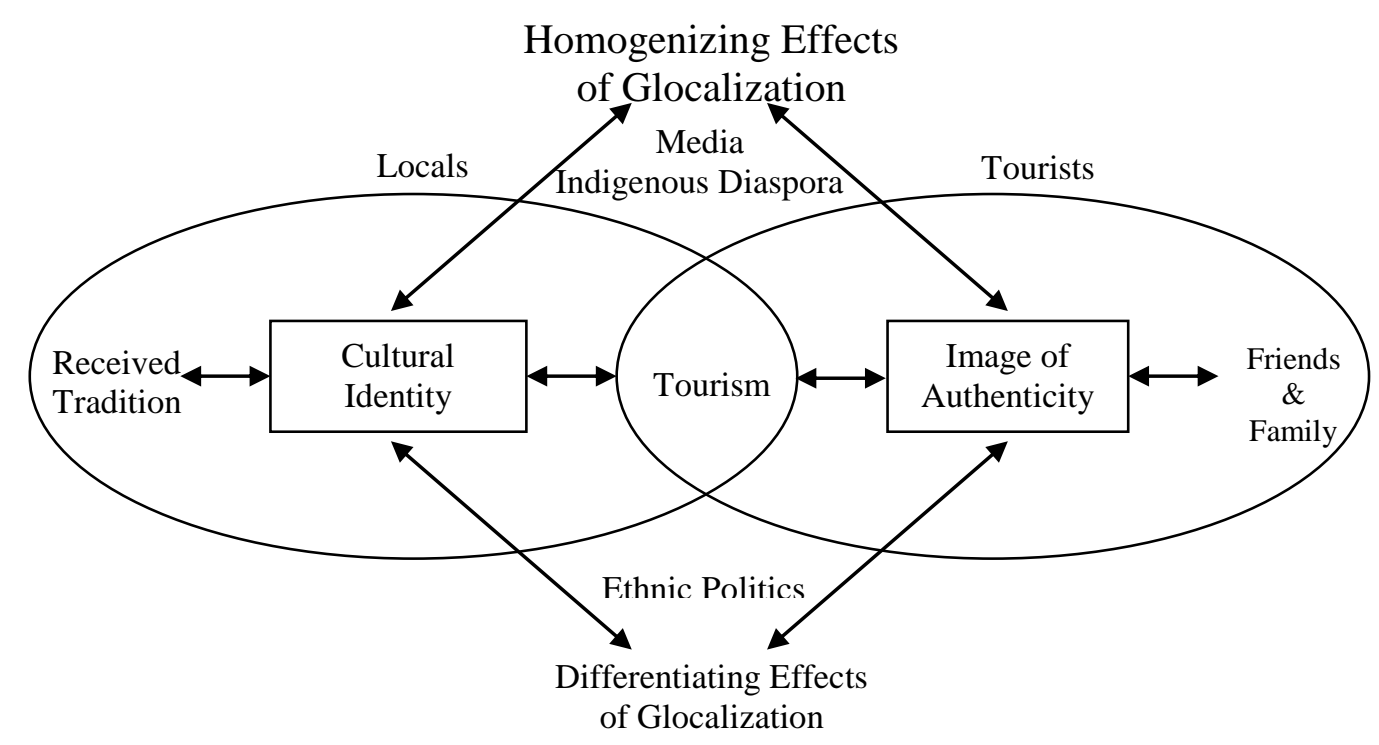

The right half of the model represents the experience of the tourist who arrives at the destination with a preconception of the local culture that has been created through the influences of modern mass media, personal experience, and the testimony of trusted friends and relatives. The left half of the model represents the experience of the indigenous local; the cultural portion of whose identity is also created through a myriad of influences. One of these is exposure to the same mass media representations of his culture that helped create the preconceptions of the tourist. To these are added the assertions of local ethnic politics, reports from expatriate friends and family, and traditions received from family and the indigenous community.

The identity of the local meets and overlaps with the preconception of the outsider through the agency of tourism. It may be obvious that the perceptions of the tourist regarding the local culture will be altered by the event. The model 
theorizes that the identity of the local is no less affected. Both parties return home with modified images of the culture that eventually change the media representations, the ethnic politics, the personal experiences, and even the received traditions of the host culture.

In reference to the authenticity / identity model (fig. 1) and using the Polynesian Cultural Center as an example, it is evident that tourists form an image of "authentic" Polynesia before their arrival in Hawaii. Their preconceived image of authenticity is created by movies they may have seen such as Mutiny on the Bounty, Paradise Hawaiian Style, 50 First Dates or Blue Crush. It may be influenced by the music of Israel Kamakawiwo'ole or even Don Ho. They may have retained images from the pages of National Geographic magazine that they vaguely connect with Polynesia. Family and friends who have visited Polynesia are also an influence. In addition they may well have had personal contact and experience with some expatriate participant in the significant Polynesian Diaspora. All of these influences and more result in a preconceived image of authenticity that tourists bring with them to the PCC.

At the PCC, they come in contact with student workers - totally modern indigenous people from throughout Polynesia whose identity contains a cultural component formed to some degree by the same media influences experienced by the tourist. In addition, they are influenced to a varying extent by an image formed by local ethnic politics. That influence tends to be greater for students from Hawaii and New Zealand where they are aboriginal minorities than it is for students from Samoa and Tonga where they constitute a solid majority of the population. They are also influenced by the experiences of their friends and relatives who live or have lived or studied abroad. Finally, their cultural identity is influenced by traditions received from parents, grandparents and community leaders. When, at the PCC, the preconceived image of authenticity held by tourists confronts the felt cultural identity of the indigenous student worker - both are modified. In tourism's commercial context, an image is negotiated that satisfies the tourist's expectations, largely by confirming his positive preconception. Simultaneously, an identity is negotiated that both confirms and enhances the student-worker's appreciation of his culture's positive dissimilarity from the hegemonic culture of the West.

The tourist returns home with his modified image of authenticity. Ultimately the modifications become a part of the media representations. They are passed on to influence the expectations of friends and family. Just so, the student-worker goes home with his modified identity. Ultimately the modifications inform and influence ethnic politics and even tradition as in the case of the fire-knife dance. Tourists feel and perceive an authenticity that is at no point referenced to some historically documented era of cultural purity. Indigenous people likewise feel and perceive their cultural identity only vaguely in reference to historical facts. They assert rather than receive their identity in relation to the global culture.

If cultural authenticity is the primary concern, indigenous people are the victims of tourism. If the concern is rather identity, tourism empowers 
indigenous people. Our study of the PCC reveals that in this case at least, indigenous people feel empowered by their control of their cultural identity. As applied to other touristic venues of cultural representation, this argues for diligent efforts by indigenous people take control of the way they are represented. In this way tourism can bring positive cultural benefits along with the positive economic benefits.

Further research is required to test this theory in relation to other traditional cultures that are subject to tourist visitation as well as to indigenous cultures that are not as yet exposed to tourism. If the theory holds, indigenous people exposed to globalization generally, but not to tourism specifically, will feel a weaker sense of cultural identity and will feel a stronger pull towards cultural homogenization. To quote Yamashita one more time: "It may be the case that a seemingly frivolous subject like tourism is actually more important than a serious subject such as cultural relativism for understanding cultural production in the age of globalization" (2003, p. 21).

\section{References}

Akiba, D. 2007 Ethnic Retention as a Predictor of Academic Success: Lessons from the Children of Immigrant Families and Black Children. The Clearing House. 80: $223-226$.

American Psychiatric Association 2000 Diagnostic and statistical manual of mental disorders (Revised 4th ed.). Washington, DC: Author.

Belhassen, Y. and Caton, K. 2006 Authenticity Matters. Annals of Tourism Research. 33:853-856.

Boorstein, D. 1964 The Image: A Guide to Pseudo-Events in America. New York: Harper.

Braun, R. 1965 Sozialer und Kultureller Wandel in Einem Landlichen Industriegebiet im 19. und 20. Jahrhundert, ch 6 (Erlenbach-Zurich, 1965).

Cohen, E. 1979 Rethinking the Sociology of Tourism. Annals of Tourism Research 6:18-35. 1988 Authenticity and Commoditization in Tourism. Annals of Tourism Research. 15:371-386.

Connell, J and Lowe, A. 1997 Generating grounded theory from qualitative data: the application of inductive methods in tourism and hospitality management research. Progress in Tourism and Hospitality Research. 3: 165-173.

Cote, J. and Levine, C. 2002 Identity Formation, Agency and Culture: A Social Psychological Synthesis. London: Lawrence Erlbaum Associates.

Crapanzano, V. 1980 Tuhami: Portrait of a Moroccan. Chicago: University of Chicago Press.

Duval, D. 2004 Cultural Tourism in Postcolonial Environments: Negotiating Histories, Ethnicities and Authenticities in St. Vincent, Eastern Caribbean. Tourism and Post Colonialism. Edited by Hall, C. and Tucker, H. London: Routledge.

Eisenhardt, K. 1989 Building Theories from Case Study Research. The Academy of Management Review. 14: 532-550.

Eisenstadt, S. N. 1972 lntellectuals and Tradition. Daedalus (Spring):1-20. 
Elkin, A.P. 1967 A Food Gathering People and European Settlement in Australia. in Bohannan, P. and Plog, F. (eds) Beyond the Frontier: Social Process and Cultural Change. New York: Natural History Press.

Ferre, C. 1988 A history of the Polynesian Cultural Center's 'Night Show': 19631983. Provo, Utah: Brigham Young University Press.

Fjellman, S.M. 1992 Vinyl Leaves: Walt Disney World and America. Boulder: Westview Press.

Gans, H. J. 1979 Symbolic Ethnicity: The Future of Ethnic Groups and Cultures in America. Ethnic and Racial studies 2:9-17.

Greenwood, D. 1977 Culture by the Pound: Anthropological Perspectives on Tourism as Cultural Commoditization. in Smith, V.L. (ed), Hosts and Guests: The Anthropology of Tourism. Philadelphia: University of Pennsylvania Press.

Handler, R. 1984 On Sociocultural Discontinuity: Nationalism and Cultural Objectification in Quebec. Current Anthropology. 25:55-7 1.

Hanson, A. 1989 The Making of the Maori: Culture Invention and Its Logic. American Anthropologist, New Series. 91:890-902.

Hobshawm, E. and Ranger, T. (eds.) 1983 The Invention of tradition. Cambridge: Cambridge University Press.

Horne, D. 1986 The Public Culture: The Triumph of Industrialism. London: Pluto Press.

Hottola, P. 2004 Culture Confusion: Intercultural Adaptation in Tourism. Annals of Tourism Research. 31: 447-6 6.

Hughes, G. 1995 Authenticity in Tourism. Annals of Tourism Research. 22:781-803.

Jamal, T. and Hill, S. 2008 Developing a Framework for Indicators of Authenticity: the Place and Space of Cultural and Heritage Tourism. in Prideaux, et. al. (eds.) Cultural and Heritage Tourism in Asia and the Pacific. London: Routledge.

Krippendorf, J. 1987 The Holiday Makers: Understanding the Impact of Leisure and Travel. London: Heinemann.

Letuli, F. 2004 Flaming Sword of Samoa: the Story of the Fire Knife Dance. Pago Pago, American Samoa: Watermark Publishing.

Linnekin, J. S. 1983 Defining Tradition: Variations on the Hawaiian Identity. American Ethnologist. 10:241-252.

Linnekin, J. and Poyer, L. 1990 Cultural Identity and Ethnicity in the Pacific. Honolulu: University of Hawaii Press.

Lowi, T. 1964 Review: American Business, Public Policy, Case-Studies, and Political Theory. World Politics. 16: 677-693+.

MacCannell, D. 1976 The Tourist: A New Theory of the Leisure Class. New York: Schocken Books. 1992 Empty Meeting Grounds: The Tourist Papers. London: Routledge.

McKercher, B. and du Cros, H. 2002 Cultural Tourism: The Partnership between Tourism and Cultural heritage Management. Binghampton, NY: Hayworth Press.

Oakes, T. S. 1997 Ethnic Tourism in Guizhou: Sense of Place and the Commerce of Authenticity. in Picard, M. and Wood, R. E. (eds.) Tourism, Ethnicity, and the State in Asian and Pacific Societies. Honolulu: University of Hawaii Press.

O'Brien, R. 1983 Hands Across the Water: the Story of the Polynesian Cultural Center. Laie, Hawaii: Polynesian Cultural Center.

Prideaux, B., Timothy, D., Chon, K. 2008 Cultural and Heritage Tourism in Asia and the Pacific. London: Routledge.

Reisinger, Y. and Steiner, C. J. 2006 Reconceptualizing object authenticity. Annals of Tourism Research 33:65-86. 
Riley, R. 1995 Prestige-worthy tourism behavior. Annals of Tourism Research. 22: 630-649.

Robertson, R.1997 Comments on the 'Global Triad' and 'Glocalization' in Inoue, N. (ed.) Globalization and Indigenous Culture. Kokugakuin University: Institute for Japanese Culture and Classics.

Ryan, C. 1999 Some Dimensions of Maori Involvement in Tourism. in: Robinson, M. and Boniface, P. (eds.) Tourism and Cultural Conflicts. New York: CABI Publishing.

Ryan, C. 2005 Tourist-Host nexus: Research Considerations. in Ryan, C. and Aicken, M. (eds.)_Indigenous Tourism: The Commodification and Management of Culture. OxFord: Elsevier

Sissons, J. 2005 First Peoples: Indigenous Peoples and Their Futures. London: Reaktion Books, Ltd.

Swapp, W. 1999 Retired BYUH faculty and former director of the Polynesian Panorama. Interview by author, 19 October. Tape recording. BYU-Hawaii, Laie Hawaii.

Swidler, A. 1986 Culture in Action: Symbols and Strategies. American Sociological Review. 51: 273-286.

Tellis, W. 1997 Application of a Case study Methodology. The Qualitative Report. 3: 3

Thibault, P. and Bourgeois, U. 2006 The Effect of Group-Identification on Emotion Recognition: The case of Cats and Basketball Players. Journal of Experimental Social Psychology. 42:676.

Tsuda, T. 2000 The Benefits of Being Minority: The Ethnic Status of the JapaneseBrazilians in Brazil. Working Paper 21. Center for Comparative Immigration Studies: University of California at SanDiego.

Wallerstein, I. 1974 The Modern World System. New York: Academic Press.

Wang, N. 1999 Rethinking Authenticity in Tourism Experience. Annals of Tourism Research. 26:349-370.

Wang, Y. 2007 Customized Authenticity Begins at Home. Annals of Tourism Research. 34:789-804.

Waters, M.C. 1990 Ethnic Options: Choosing Identities in America. Berkeley: University of California Press.

Weigert, A.J., Teitge, J.S., Teitge, D.W. 1986 Society and Identity: Toward a Sociological Psychology. Cambridge: Cambridge University Press.

Wood, R. 1993 Tourism, Culture, and the Sociology of Development. In Hitchcock, M. et. al. (eds.) Tourism in South-East Asia. London: Routledge.

Wrigley, E.A. 1992 Why Poverty Was Inevitable in Traditional Societies. in Hall, John A. and Jarvie, I.C. (eds.)_Transition to Modernity: Essays on Power, Wealth and Belief. New York: Cambridge University Press.

Yamashita, S. 2003 Bali and Beyond: Explorations in the Anthropology of Tourism. New York: Bergham Books.

Yin, R. K. 1984 Case Study Research: Design and Methods. London: Sage. 